\title{
FSN-NU 0015 \\ LYSINE REQUIREMENT AND ITS EFFECT ON THE BODY COMPOSITION OF OREOCHROMIS NILOTICUS FINGERLINGS
}

\author{
OVIE S. O. AND EZE S. S. \\ National Institute for Freshwater Fisheries Research, New Bussa, Niger State
}

Copyright 2010, Fisheries Society of Nigeria.

This paper was prepared for presentation at the $25^{\text {th }}$ Annual International Conference and Exhibition in Administrative Staff College of Nigeria (ASCON), Topo-Badagry, Lagos, Nigeria, $25^{\text {th }}-29^{\text {th }}$ Octo Cober, 2010.

This paper was selected for presentation by an FISON Program Committee following review of information contained in an abstract submitted by the author(s). Contents of the paper, as presented, have not been reviewed by the Fisheries Society of Nigeria and are subject to correction by the author(s). The material, as presented, does not necessarily reflect any position of the Fisheries Society of Nigeria, its officers, or members. Papers presented at FISON meetings are subject to publication review by Editorial Committees of the Fisheries Society of Nigeria. Electronic reproduction, distribution, or storage of any part of this paper for commercial purposes without the written consent of the Fisheries Society of Nigeria is prohibited. Permission to reproduce in print is restricted to an abstract of not more than 300 words; illustrations may not be copied. The abstract must contain conspicuous acknowledgement of where and by whom the paper was presented. Write Librarian, Fisheries Society of Nigeria (FISON), P. O. Box 2607 Apapa, Lagos.

\section{ABSTRACT}

This study was carried out to investigate the lysine requirement and its effect on the body composition of Oreochromis niloticus fingerlings. Two hundred and seventy fingerling $O$. niloticus (9.01 $11.09 \mathrm{~g}$ ) were reared in $35 \mathrm{~L}$ plastic troughs. Six diets were formulated, containing 35\% crude protein. The diets were formulated with ingredients deficient of lysine (Groundnut cake $-3.23 \mathrm{~g}$ lysine $1100 \mathrm{~g}$ diet and guinea corn $-1.9 \mathrm{~g}$ lysine/100g diet) for $O$. niloticus having whole body content of $7.51 \mathrm{~g}$ lysine $/ 100 \mathrm{~g}$ protein. The diets consist of a basal diet (Diet I, no added lysine), while the test diets (II, III, IV and V) had 4.56g, 6.87g, $7.30 \mathrm{~g}, \quad 7.41 \mathrm{~g}$ lysine $/ 100 \mathrm{~g}$ protein respectively. The reference diet was made of Clupeids (mixture of Pellonula afzeliusi and Physalia pellucida), groundnut cake and guinea corn but no added lysine (5.37g lysine $100 \mathrm{~g}$ protein). The fish were fed twice daily (0900 and 18.00hrs) at 3\% body weight for 56 days. There was significant difference in the mean weight gain and food conversion efficiency $(P<0.05)$. The four levels of lysine resulted in quadratic responses $(P<0.05)$. Calculation using regression equations from the relationship between the specific growth rate, weight gain and lysine levels show that lysine requirement for fingerling was $7.12 \mathrm{~g} / 100 \mathrm{~g}$ protein respectively. The requirement of $O$. niloticus for lysine is $7.12 \mathrm{~g}$ lysine $100 \mathrm{~g}$ protein.

\section{INTRODUCTION:}

Lysine has one major function of protein deposition in animal body. It is the second most limiting amino acid (Robinson and $\mathrm{Li}$, 2007). Lysine helps the absorption of calcium, maintain healthy blood vessels, produce antibodies, enzymes, collagen and repairs of tissues. A typical commercial production diet formulated for tilapia or catfish contains approximately $32-40 \%$ protein (Miles and Chapman 2008). Fish do not have a specific protein requirement but rather a definite requirement for essential amino acids that comprise proteins. Lysine is the most important amino acid, accounting for $7.2 \%$ of protein. Lysine is the first limiting essential amino acid in many protein sources used for feed and lysine richingredients are often expensive. According to Miles and Chapman, (2008), if fish feed contains the exact amount of EAA required by a fish species then the ideal protein for that species is met, and so no amino acid deficiency or excess. The growing fish fed such diet would use very few amino acids for energy. The amino acids would be used efficiently for maintenance, health, and synthesis of new structural proteins which would result in maximum feed efficiency and growth. NRC (1993) reported $O$. niloticus require $14 \mathrm{~g}$ lysine/kg diet while Santiago and Lovell (1988) observed that $O$. niloticus requires $14.3 \mathrm{~g}$ lysine $/ \mathrm{kg}$ diet. Other species of fish studied are Oreochromis mossanbicus $16 \mathrm{~g}$ lysine $/ \mathrm{kg}$ diet; Ictalurus 
punctatus $12 \mathrm{~g}$ lysine $/ \mathrm{kg}$ diet; Clarias gariepinus $23 \mathrm{~g}$ lysine $/ \mathrm{kg}$ diet and Cyprinus carpio $22 \mathrm{~g}$ lysine/ $\mathrm{kg}$ diet. Encarnacao et al., (2004) reported increase in feed intake and growth with increased dietary lysine level. Further to this, they reported that efficiency of lysine utilization for whole body protein deposition was affected both by lysine and digestible energy levels in the diet.

Pere and Oliva - Teles, (2007) also reported increased weight gain and final body weight with increased dietary lysine levels for Scophthalmus maximus juvenile, although they observed that voluntary food intake was not affected by dietary lysine diet. Ruchimat et al., (1998) observed that weight gain, feed efficiency, protein efficiency ratio and nitrogen retention increased for Seriola quinqueradiata with increasing levels of dietary lysine up to $1.85 \mathrm{~g} / 100 \mathrm{~g}$ diet and remained nearly the same thereafter. According to Bureau and Encarnacao, (2006), published estimates of lysine requirements for rainbow trout varied as widely $(1.3-2.9 \mathrm{~g} / 100 \mathrm{~g}$ of diet $)$. They further observed that the experimental design and condition between the different laboratories/experiments may be contributory (Kim et al., 1992a; Wilson, 1993; Cowey, 1994; Hauler and Carter 2001a and b). NRC (1993) observed that the lysine requirements of fish range from 5.0 to $6.8 \%$ of dietary protein, the highest value being the nutritional requirements of carnivorous fish. Bureau and Encarnacao (2006) also observed that growth rates achieved with the semi purified diets used were much lower than when practical diets were used. Adequate dietary lysine contents improve survival and growth rate and prevent erosion and deformities of fish dorsal, pectoral and ventral fin
(Keembiyehetty and Gatlin, 1992). Lysine is beneficial to fish because it helps absorption of calcium, maintain healthy blood vessels, produce antibodies, enzymes, collagen and repairs of tissues, it also produces carnitine which helps to convert fatty acids into energy and maintain cholesterol in the blood. This study was carried out to investigate the lysine requirement and its effect on the body composition of $O$. niloticus fingerlings.

\section{MATERIALS AND METHODS}

Six diets were formulated, containing $35 \%$ crude protein. The diets were formulated with ingredients deficient of lysine (Groundnut cake -3.23g lysine/100g protein and guinea corn $-1.9 \mathrm{~g} / 100 \mathrm{~g}$ protein) for $O$. niloticus fingerling as the whole body content is $7.51 \mathrm{~g}$ lysine $/ 100 \mathrm{~g}$ protein (Table 3 ). The diets were made up of a basal diet (Diet I, no added lysine), while the test diets (II, III, IV and V) had $4.56 \mathrm{~g}, \quad 6.87 \mathrm{~g}, \quad 7.30 \mathrm{~g}, \quad 7.41 \mathrm{~g}$ lysine $/ 100 \mathrm{~g}$ protein respectively. The reference diet (VI) was made of Clupeids (mixture of Pellonula afzeliusi and Physalia pellucida), groundnut cake and guinea corn but no added lysine $(5.37 \mathrm{~g}$ lysine $/ 100 \mathrm{~g}$ protein). The fixed components of all the diets were oil, premix, vitamin $\mathrm{C}$ and starch. Table 1 shows the composition of the ingredients while Table 2 shows the composition of experimental diets $\mathrm{g} / \mathrm{kg}$. The amino acid profile of $O$. niloticus was used as reference dietary amino acids profile (Table 3). The diets were formulated, pelleted and sun dried for three days. The amino acid composition of the diets was analyzed using Technicon TSM- 1 multiple analyzer (Table 
Table 1: Proximate composition of ingredients

\begin{tabular}{lllllll}
\hline Ingredients & Moisture & Protein & Lipid & $\begin{array}{l}\text { Crude } \\
\text { fibre }\end{array}$ & Ash & NFE \\
\hline Groundnut cake & 4.85 & 41.02 & 41.30 & 0.70 & 5.65 & 6.48 \\
Fishmeal & 4.95 & 63.44 & 21.95 & 0.80 & 11.49 & Nil \\
Guinea corn & 6.93 & 11.17 & 17.10 & 1.60 & 2.18 & 61.02 \\
\hline
\end{tabular}

The experiment was in factorial design of six treatments, replicated thrice $(6 \times 3)$.

$O$. niloticus fingerlings of mean weight 9.01-11.09g were obtained from the National Institute for Freshwater Fisheries Research hatchery complex New Bussa Nigeria and randomly distributed into eighteen $35 \mathrm{~L}$ plastic troughs. The fish were fed twice daily (0900 and 18.00hrs) at $3 \%$ body weight for 56 days. All troughs were well aerated using air pumps, cleared of feed remnants and faecal materials. Water was replaced daily to make up for that siphoned out, while complete replacement was done on every sampling day. Fish were sampled by bulk weighing biweekly. Samples of five fish was analyzed before and after the experiment for carcass composition and amino acid composition.

Table 2: Composition of experimental diets $(\mathrm{g} / \mathrm{kg})$

\begin{tabular}{lllllll}
\hline Ingredients & Diet I & Diet II & Diet III & Diet IV & Diet V & Diet VI \\
\hline $\begin{array}{l}\text { Groundnut } \\
\text { Cake }\end{array}$ & 646.62 & 638.64 & 622.67 & 606.71 & 590.74 & 235.00 \\
Lysine & 0 & 10.00 & 30.00 & 50.00 & 70.00 & 0 \\
Fish meal & - & - & - & - & - & 235.00 \\
Guinea corn & 163.38 & 161.36 & 157.33 & 153.29 & 149.26 & 340.00 \\
Cod liver Oil & 100.00 & 100.00 & 100.00 & 100.00 & 100.00 & 100.00 \\
Premix & 60.00 & 60.00 & 60.00 & 60.00 & 60.00 & 60.00 \\
Starch & 20.00 & 20.00 & 20.00 & 20.00 & 20.00 & 20.00 \\
Vitamin C & 10.00 & 10.00 & 10.00 & 10.00 & 10.00 & 10.00 \\
\hline
\end{tabular}

Table 3: Amino acid composition of Oreochromis niloticus

\begin{tabular}{lcc}
\hline AMINO ACIDS & $\begin{array}{c}\text { COMPOSITION g/100g protein } \\
\text { for Fry }\end{array}$ & $\begin{array}{c}\text { COMPOSITION g/100g protein } \\
\text { for Fingerlings }\end{array}$ \\
\hline Lysine & 5.30 & 7.51 \\
Histidine & 2.24 & 2.39 \\
Arginine & 5.01 & 6.04 \\
Aspartic acid & 7.85 & 8.19 \\
Threonine & 3.23 & 4.03 \\
Serine & 3.66 & 4.01 \\
Glutamic acid & 10.23 & 13.63 \\
Proline & 3.87 & 4.45 \\
Glycine & 4.13 & 7.25 \\
Alanine & 4.48 & 6.46 \\
Cystine & 0.79 & 0.71 \\
Valine & 4.10 & 4.80 \\
Methionine & 2.19 & 2.40 \\
Isoleucine & 3.49 & 3.99 \\
Tyrosine & 3.18 & 7.15 \\
Phenylalanine & 3.51 & 2.86 \\
Leucine & 6.25 & 3.77 \\
\hline
\end{tabular}


Statistical analysis was done using SPSS version 10. Polynomial regression curves were graphically represented for the mean weight gain Food conversion efficiencies, protein efficiency ratio and the specific growth rate were utilized to determine the requirement. The second order polynomial equation was also calculated for the requirement of lysine. One - Way Analysis of Variance (ANOVA), Student Newman Keul's (SNK) and Duncan's multiple range test was employed to test for the significance of the parameters. The growth parameters were calculated as follows:

Mean Weight Gain $(\mathrm{MWG})=\mathrm{Wt}-\mathrm{Wo}_{\mathrm{o}}$

$\mathrm{Wo}=$ Mean initial weight $; \mathrm{Wt}=$ Mean final weight

Specific Growth Rate (SGR) (\%/day) = $100 \times(\ln \mathrm{Wt}-\ln \mathrm{Wo}) /$ days

Feed Conversion Efficiency $(\mathrm{FCE})=$ Weight gain $(\mathrm{g}) /$ dry food intake

Protein Efficiency Ratio (PER) $=$ (weight gain per fish $\times 100) / \mathrm{N} \times 6.25$ given per fish

$\mathrm{N}=$ Nitrogen content of feed

Table 4: Essential Amino Acid composition of diets

\begin{tabular}{lllllll}
\hline $\begin{array}{l}\text { AMINO } \\
\text { ACID }\end{array}$ & DIET I & DIET II & DIET III & DIET IV & DIET V & DIET VI \\
\hline Lysine & 4.56 & 6.87 & 7.30 & 7.41 & 7.51 & 5.37 \\
Histidine & 2.32 & 2.19 & 2.32 & 2.38 & 2.57 & 2.38 \\
Threonine & 2.39 & 2.55 & 2.72 & 2.83 & 2.77 & 2.66 \\
Arginine & 4.76 & 5.28 & 4.93 & 5.44 & 5.79 & 4.76 \\
Valine & 3.83 & 3.95 & 4.24 & 4.41 & 4.18 & 4.07 \\
Methionine & 1.67 & 1.72 & 2.11 & 1.77 & 1.88 & 2.14 \\
Isoleusine & 3.08 & 3.26 & 2.89 & 2.95 & 3.32 & 3.14 \\
Leucine & 7.58 & 7.80 & 8.24 & 8.34 & 7.80 & 8.13 \\
Tyrosine & 3.38 & 3.38 & 3.61 & 3.70 & 3.54 & 3.31 \\
Phenylalnine & 5.92 & 4.40 & 4.23 & 4.40 & 4.56 & 4.22 \\
\hline
\end{tabular}

\section{RESULTS AND DISCUSSION}

There was significant difference in the mean weight gain and food conversion efficiency $(\mathrm{P}<0.05)$ (Table 5). The four levels of lysine resulted in quadratic responses $(\mathrm{P}<0.05)$.

The mean weight gain, food conversion efficiency and protein efficiency ratio all resulted in minima at diet III $(7.30 \mathrm{~g}$ lysine $/ 100 \mathrm{~g}$ protein). When the specific growth rate was regressed on levels of lysine there was an exponential relationship from fish fed $7.30 \mathrm{~g}$ to $7.51 \mathrm{~g}$ lysine $/ 100 \mathrm{~g}$ protein. The regression coefficients $\left(\mathrm{r}^{2}\right)$ for mean weight gain and food conversion ratio are 0.854 and 0.54 respectively. Analysis of the growth data showed a minimum at $7.30 \mathrm{~g}$ lysine/ $100 \mathrm{~g}$ protein of diet and rose to the highest point of $7.51 \mathrm{~g}$ lysine/ $100 \mathrm{~g}$ protein. The quadratic equation of this relationship between weight gain, specific growth rate and lysine shows that lysine requirement for $O$. niloticus fingerlings was $7.12 \mathrm{~g} / 100 \mathrm{~g}$ protein.

$O$. niloticus fingerlings responded positively to the highest level of lysine. This is an indication that at this level the relationship of lysine and other essential amino acids was not impaired. Jackson and Capper (1982) reported 4.1g lysine/100g protein for $O$. mossambicus while Santiago and Lovell, (1988) and NRC, (1993) reported $5.13 \mathrm{~g}$ lysine $/ 100 \mathrm{~g}$ protein and $5.1 \mathrm{~g}$ lysine $/ 100 \mathrm{~g}$ protein respectively for O. niloticus requirement which are slightly 
lower than the requirement obtained in this study. This may be attributed to the observation made by Bureau and Encaarnacao (2006) that growth rates achieved with the semi purified diets in experiments were much lower than when practical diets were used.

Table 5: Growth parameters of $O$. niloticus fingerlings fed varying levels of lysine for 56 days

\begin{tabular}{lllllll}
\hline $\begin{array}{l}\text { Growth } \\
\text { parameters }\end{array}$ & Diet I & Diet II & Diet III & Diet IV & Diet V & Diet VI \\
\hline MIW & $11.09 \pm 3.84$ & $9.01 \pm 1.84$ & $9.09 \pm 1.90$ & $11.09 \pm 3.84$ & $11.09 \pm 3.84$ & $9.20 \pm 1.54$ \\
MFW & $24.96 \pm 6.93$ & $13.70 \pm 2.32$ & $17.81 \pm 4.12$ & $17.57 \pm 3.20$ & $21.14 \pm 5.92$ & $10.28 \pm 2.17$ \\
MWG & $13.89 \pm 1.67^{\mathrm{d}}$ & $4.69 \pm 0.73^{\mathrm{b}}$ & $8.72 \pm 1.14^{\mathrm{c}}$ & $8.15 \pm 1.36^{\mathrm{c}}$ & $13.38 \pm 2.48^{\mathrm{d}}$ & $1.08 \pm 0.07^{\mathrm{a}}$ \\
SGR & $0.72 \pm 0.71^{\mathrm{c}}$ & $0.44 \pm 0.30^{\mathrm{b}}$ & $0.77 \pm 0.37^{\mathrm{b}}$ & $0.80 \pm 0.33^{\mathrm{b}}$ & $1.09 \pm 0.53^{\mathrm{c}}$ & $0.16 \pm 0.01^{\mathrm{a}}$ \\
PER & $4.8 \pm 3.32^{\mathrm{a}}$ & $1.42 \pm 1.08^{\mathrm{a}}$ & $2.91 \pm 1.90^{\mathrm{a}}$ & $3.07 \pm 1.49^{\mathrm{a}}$ & $4.60 \pm 2.7^{\mathrm{a}}$ & $0.54 \pm 0.09^{\mathrm{a}}$ \\
FCE & $14.37 \pm 4.24^{\mathrm{c}}$ & $2.97 \pm 0.29^{\mathrm{b}}$ & $3.51 \pm 2.33^{\mathrm{b}}$ & $4.39 \pm 1.06^{\mathrm{b}}$ & $14.18 \pm 8.21^{\mathrm{c}}$ & $0.79 \pm 0.09^{\mathrm{a}}$ \\
\hline
\end{tabular}

Figures in the same row with the same superscript are not significantly different $(\mathrm{P}>0.05)$

MIW- Mean Initial Weight ; MFW- Mean Final Weight; MWG- Mean Weight Gain; SGR- Specific Growth Rate; PER- Protein Efficiency Ratio; FCE- Food Conversion Efficiency

Carcass composition shows that protein and fat increased while moisture, ash and crude fibre decreased except for ash in the reference diet (Table 6). The positive increase in carcass protein observed in all treatments shows that there was deposition of tissue. Fish fed diet I, which is the basal diet had crude protein level similar to others with additional lysine indicating that the levels of lysine supplied did not make any difference in the deposition of protein observed although in the somatic growth of the fish it contributed positively throughout the experiment. According to Bureau and Encarnoacao, (2006) the efficiency of utilization of dietary free amino acids differs among published reports. Williams et al., (2001) observed that the efficiency of the utilization of crystalline amino acids is dependent on dietary protein level. In this study the reference diet had only intact protein as the basal diet but the response of the fish to the diets varied being better in the basal diet than the reference. The carcass protein of the fish fed the basal diet $(18.17 \%)$ and that fed the reference diet $(18.85 \%)$ were not significantly different $(\mathrm{P}>0.05)$. This shows that the utilization of animal protein in the diet of $O$. niloticus does not have an advantage (Robinson and Menghe, 2007). The diets supplied also positively affected the percentage fat deposited during the rearing period, this may have contributed to the weight gain observed at harvest.

Water quality parameters in this experiment showed that temperature ranged from $28-31^{\circ} \mathrm{C}, \mathrm{pH} 7.4$, Dissolved oxygen from $0.5-7.8 \mathrm{mg} / \mathrm{L}$ and conductivity from $44-3100 \mu \mathrm{cm}^{3}$. 
Table 6: Carcass composition of $O$. niloticus fingerlings fed varying levels of lysine for 56 days

\begin{tabular}{lllllll}
\hline & $\%$ Moisture & $\%$ Ash & $\begin{array}{l}\text { \% Crude } \\
\text { fibre }\end{array}$ & $\begin{array}{l}\text { \% Crude } \\
\text { protein }\end{array}$ & \% Lipid & \% NFE \\
\hline Diet I & 71.30 & 2.40 & 0.90 & 18.17 & 7.06 & 0.17 \\
Diet II & 74.08 & 3.60 & 0.30 & 18.51 & 3.30 & 0.21 \\
Diet III & 70.98 & 3.40 & 0.10 & 17.84 & 7.60 & 0.08 \\
Diet IV & 76.00 & 2.30 & 0.20 & 18.17 & 3.30 & 0.03 \\
Diet V & 71.20 & 3.60 & 0.10 & 15.82 & 8.60 & 0.68 \\
Diet VI & 73.00 & 4.10 & 0.25 & 18.85 & 3.80 & Neg. \\
Initial & 78.60 & 3.69 & 2.28 & 12.30 & 3.00 & 0.03
\end{tabular}

No morphological deficiency signs were observed in fish fed the varying levels of lysine. This is similar to the observation of Fagbenro et al (1998a). According to Keembiyehetty and Gatlin (1992) lysine helps production of antibodies and prevents erosion and deformities in fins.

\section{ACKNOWLEDGEMENT}

This study was funded by the Federal Republic of Nigeria, through National Institute for Freshwater fisheries Research, New Bussa.

\section{REFERENCES}

Bureau Dominique P, Encarnacao Pedro $M$ (2006). Adequately defining the amino acid requirements of fish: The case example of lysine.UG/OMNR Fish nutrition Research Laboratory, Department of Animal and Poultry Science University of Guelph, Guelph, Ontario, NIG2W1 Canada

Cowey CB (1994). Amino acid requirements of fish: a critical appraisal of present values. Aquaculture. 124, 1-11

Encarnacao, P., Cornelis de Lange, Markus Rodehutscord, Dirk Hoehler, Wafa Bureau, Dominique, P. Bureau (2004). Diet digestible energy content affects lysine utilization, but not dietary lysine requirements of rainbow trout (Oncorhynchus mykiss) for maximum growth. Aquaculture 2335: 569 - 586
Encarnacao P, CFM de Lange, Bureau DP. (2006). Diet energy source affect lysine utilization for protein deposition in rainbow trout (Onchorhynchus mykiss). Aquaculture (in press).

Fagbenro OA, Balogun AM, Fasakin EA, Bello-Olusoji (1998a) Dietary lysine requirement of the African catfish, Clarias gariepinus. Journal of Applied Aquaculture 8 (2) 71-77.

Hauler R, Carter C (2001a). Re-evaluation of the quantitative dietary requirement of fish. Rev. Fish. Sci. 9, $133-163$.

Hauler R, Carter C (2001b). Lysine deposition responds linearly to marginal lysine intake in Atlantic salmon (Salmo salar L) parr. Aquaculture Research, 32 (suppl. 1), $147-156$

Jackson AJ, Capper BS (1982). Investigation into the requirements of the , Sarotherodon mossambicus for dietary methionine, lysine and arginine in semi - synthetic diets. Aquaculture, 29, 289 - 297

Kim KI, Kayes TB, Amundson CH (1992a). Requirements for lysine and arginine by rainbow trout (Oncorhynchus mykiss). Aquaculture $106,333-344$

Keembiyehetty CN, DM. Gatlin III (1992). Dietary requirement of juvenile hybrid striped bass (Morone chrysops x M. saxatilis). Aquaculture 104: 271 - 277. Ictalurus puntatus. 
Aquaculture

http://www.sciencedirect.com/scienc e?_ob=ArticleURL\&_udi=B...

Miles Richard D, Chapman Frank A (2008). The concept of ideal protein in formulation of Aquaculture feeds. Department of Fisheries and Aquatic sciences, University of florida IFAS Extension. FA 144

National Research Council (1993). Nutrient requirements of fish. Washington: National Academic Press. 114p

Peres Helena, Oliva - Teles Aires (2007). Lysine requirement and efficiency of lysine utilization in turbot (Sophthalmus maximus) juveniles. Aquaculture

http://www.sciencedirect.com/scienc e?_ob=ArticleURL\&_udi=B6T4D4RDS3YC-2\&_user=10\&_o

Robinson Edwin H, Li Menghe H (2007). Catfish protein nutrition. Delta Research and Extension Centre, Mississippi State University. MAFES Bulletin 1090.

http://www.thefishsite.com/articles/293/cat fish-protein-nutrition
Ruchimat Toni, Toshiro Masumoto, Hidetsuyo Hoso kawa, Yoshiaki Itoh, Sadao Shimeno (1998). Quantitative lysine requirement of yellow tail (Seriola quinqueradiata). http://www.sciencedirect.com/scienc e?_ob=ArticleURL\&_udi=B6T4D3553VSF-\&_user $=10$ \$_or

Santiago Corazon B, Lovell Richard T (1988). Amino acid requirements for growth of Nile Tilapia. J. Nutr $118,1540-1546$

Willams K, Barlow, Rodgers L (2001). Efficacy of crystalline and protein bound amino acid enrichment of diets for barramundi/asian seabass (Lates calcicarifer Bloch). Aquaculture Research 32, 415 - 429

Wilson RP (1993). Amino acid nutrition of fish. A new method of estimating requirement values. Proceeding of the $20^{\text {th }}$ US- Japan Symposium on Aquaculture Nutrition. Newport, Oregon. 28 - 39 October 1991. Collie, M. R. \& McVey, J. P. (Eds) pp. $49-54$ 